\author{
N.I. Domantsevych, O.V. Shunkina, B.P. Yatsyshyn
}

\title{
Influence of Operating Conditions on Structure and Physical Properties of Polymeric Materials
}

\author{
Lviv University of Trade and Economics, 79008, Ukraine, Lviv, Tugan-Baranjwsky str. 10, e-mail: \\ nina.domantzevich@gmail.com; bogdan.yatsyshyn7@gmail.com
}

\begin{abstract}
The changes of structure and physical properties of polymeric materials that exploited in a long time with complex mechanical loads used in pipe systems for high-pressure cold water have been studied. A significant reduction in mechanical properties of polymeric materials has been established. The most typical structural defects that occur in polymer materials during manufacture and in the exploitations, using electron microscopic studies identified.
\end{abstract}

Keywords: polymers, polyethylene, mechanical properties, surface structure.

Article acted received 21.05.2017; accepted for publication 05.06.2017.

\section{Introduction}

Polymeric materials widely used in modern building and engineering equipment, which lead to constantly increasing demands on their technical, physical and chemical characteristics, increasing the life cycle of such materials. One of the areas in which polymeric materials use are pipelines and pipeline equipment, which are made from different thermoplastic materials and their compositions, such as polyethylene, polypropylene, polyvinyl chloride, polybutylene, polyamide, different types of filled and thermosetting polymers. Often, for these purposes, as a major matrix material, use highdensity polyethylene (HDPE) brand PE 63, PE 80, PE 100 and PE 100+, which constantly changing and picking up new composite formulations according to the needs of consumers.

Investigation of mechanical properties of polymer samples intended for use in piping systems for water supply, do in 12 major indexes, among which should be more important such as nominal pressure, maximum operation pressure, minimum required strength, tensile yield stress, elongation at break, resistance to slow crack propagation, impact loading.

The aim of this work was to study the morphology of the surface and the mechanical properties of polymeric materials used in pipe systems for products for highpressure cold water.

\section{Experimental part}

Pipes and other details of water pipelines systems produced by injection molding from a modified composition of polyethylene of low (brand PE2NT11285D (PE 100)) and high (brand LDPE 15803-020) pressure. The use of mix polyethylene of low and high pressure was due to obtaining high physical-mechanical, technological and chemical characteristics by polymeric materials. As modifiers used a mix of phenolic and organophosphite antioxidant synergistic blend of "Irgafos ${ }^{\circledR} 168$ " and "Irganox" known as "Irganox B225FF", also used such processing additive "Dynamar FX 5911", black carbon (soot) and other colorants.

Stability at constant internal pressure determined in accordance with normative document GOST 24157-80 on three samples. Tests carried out in a bath of water with a constant temperature. The ends of samples had cap. Inside of the samples filled with water at pressure. The test results considered satisfactory if not all the samples have suffered damage during the test of time limit of 100 hours.

The yield stress and tensile elongation at break determined on five samples - "shovels". The types of the samples were chosen depending on the value of the nominal wall thickness and external nominal diameter pipes, according to GOST 26277. The investigations made using a tensile machine type 2054 P-5.

The electron microscopy investigations were carried out using scanning microscope EVO 40XVP. 


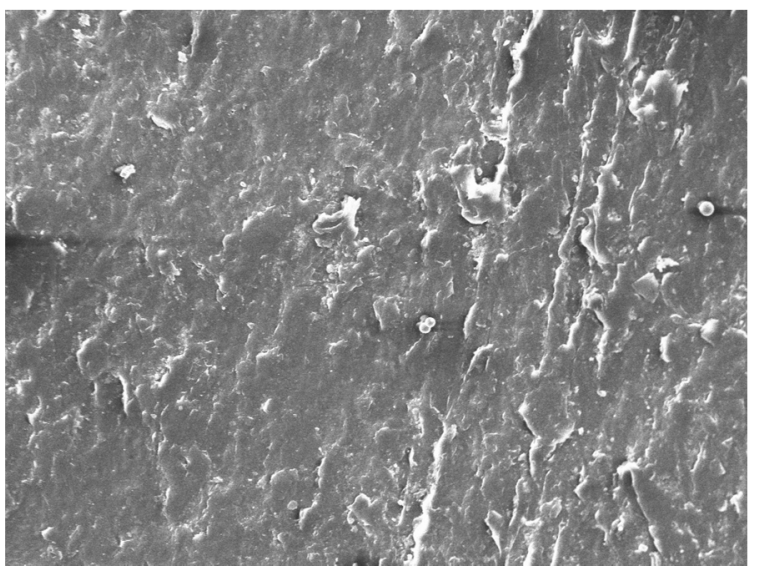

Fig. 1. Structure of the surface of the initial sample from polyethylene PE2NT11-285D modified by 7 wt. \% thermo stabilizers (X 500).

\section{Results}

The index of stability under constant internal pressure in the pipes, which were produced by 12 versions of the compositions of modified polyethylene, show according to results of investigations, that only 5 variants of these pipes have been in operating conditions more than 6 years were suitable.

The greatest stability under constant internal pressure detected the pipes made of a composition which included LDPE 15803-020 (12 to $16 \mathrm{wt}$. \%). The application of Irganox B225FF and Dynamar FX5911 (2 wt. \%) slightly increased stability performance of products on value of 8 - 10\%. The destruction accompanied with cracks, which appears on surface of tube, and causing pressure inside typical samples decrease. Initial samples of polyethylene pipes characterized by high values of tensile yield stress $\sigma_{\text {ys }}$ (from $26 \mathrm{MPa}$ for PE2NT11-285D to $33 \mathrm{MPa}$ for composite polyethylene) and had elongation at break $\mathrm{E}_{\mathrm{eb}}$

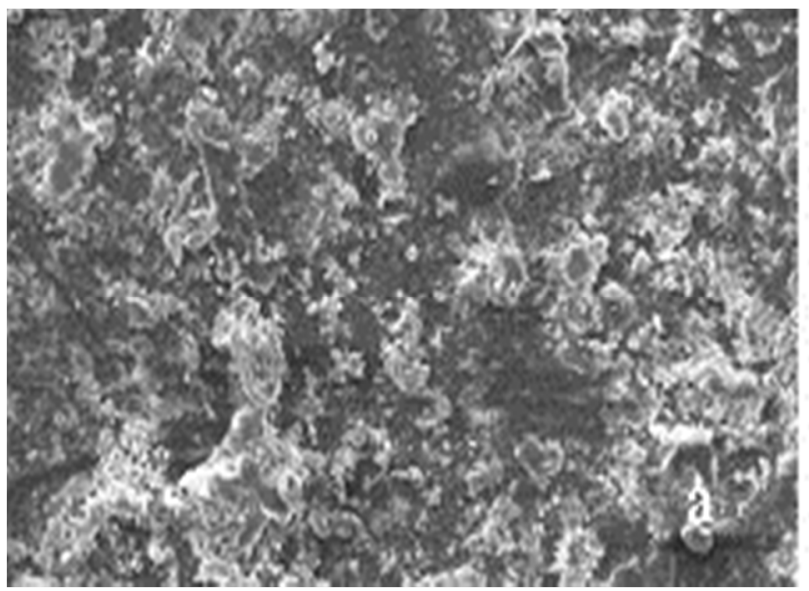

(up to $970 \%$ ). The modified samples had somewhat better results. The structure of the surface of these samples was smoother, with smaller amount defects as cracks and cavities, but some form like a drops were observed on the surface of modified examples, which include the increased amount of processing applications, thermo stabilizers and plasticizers (Fig. 1).

No visible surface defects or mechanical damage found in the samples that exploited. However, the internal surfaces of pipes covered with sediment, the structure of which coincides with the configuration of the water that was transported (Fig. 2) [1].

The value of index controlled stability of the samples, which functioning for a long time, significantly decreased and amounted to less than 80 hours. Only samples of modified composite polyethylene were exceeded the standard value on sustainability. A characteristic feature of destruction of samples in studies on the stability was direction of crack - always along the samples.

The operating during a year of polyethylene pipes made of PE2NT11-285D revealed a slight decrease in mechanical properties $-\sigma_{\mathrm{ys}}$ was lower $25.3 \mathrm{MPa}$ and $\mathrm{E}_{\mathrm{eb}}$ recorded at $930-970 \%$. The electron microscopy investigations found growing on the surface of crystallinity in these samples. The value of defects such as pores and crystalline stratums increased. Accordingly, the size of such structures is also increased. Therefore, crack width increased from 1 micron to 2 microns, and pore diameter increased from 0.5 micron to 1-1.5 microns, compared to newly prepared samples (Fig. 3).

Next the working of the pipes made from modified PE2NT11-285D not led to further deterioration of mechanical properties, but the morphology of the surface of samples became more relief. The cracks generated at the interface of phases, which led to increasing size of conglomerates. The pores, the association with which can lead to breaks matrix material, appear. The modifiers and colorants, which press out from matrix, look on some parts of surface as bubbles (Fig. 4).

The tubes from modified plastic composite, which included a PE2NT11-285D and LDPE 15803-020, stabilizers, anti-oxidants or other ingredients had most

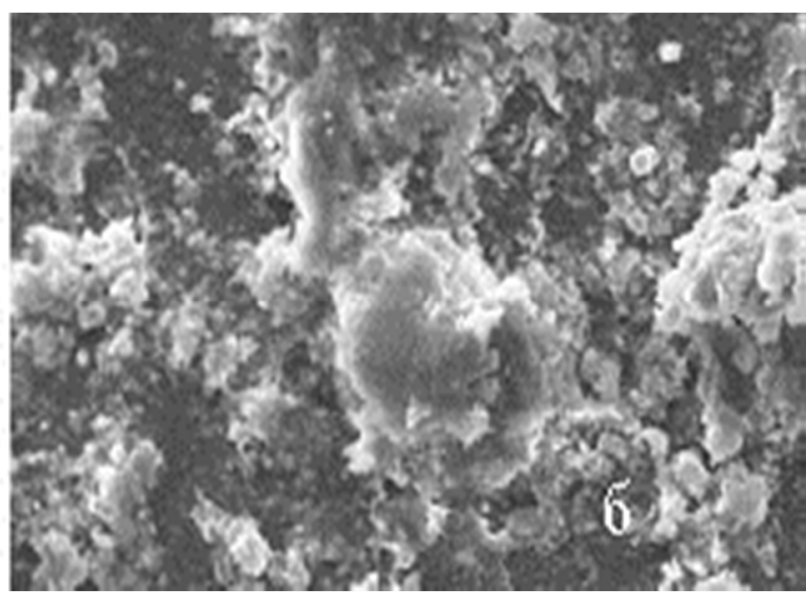

Fig. 2. Precipitation on the inner wall surface of the polymer pipe (material - PE2NT11-285D with thermo stabilizers) that worked for 6 years in water pipelines systems ( $\mathrm{a}-\mathrm{X} 500 ; \mathrm{b}-\mathrm{X} 2000)$. 

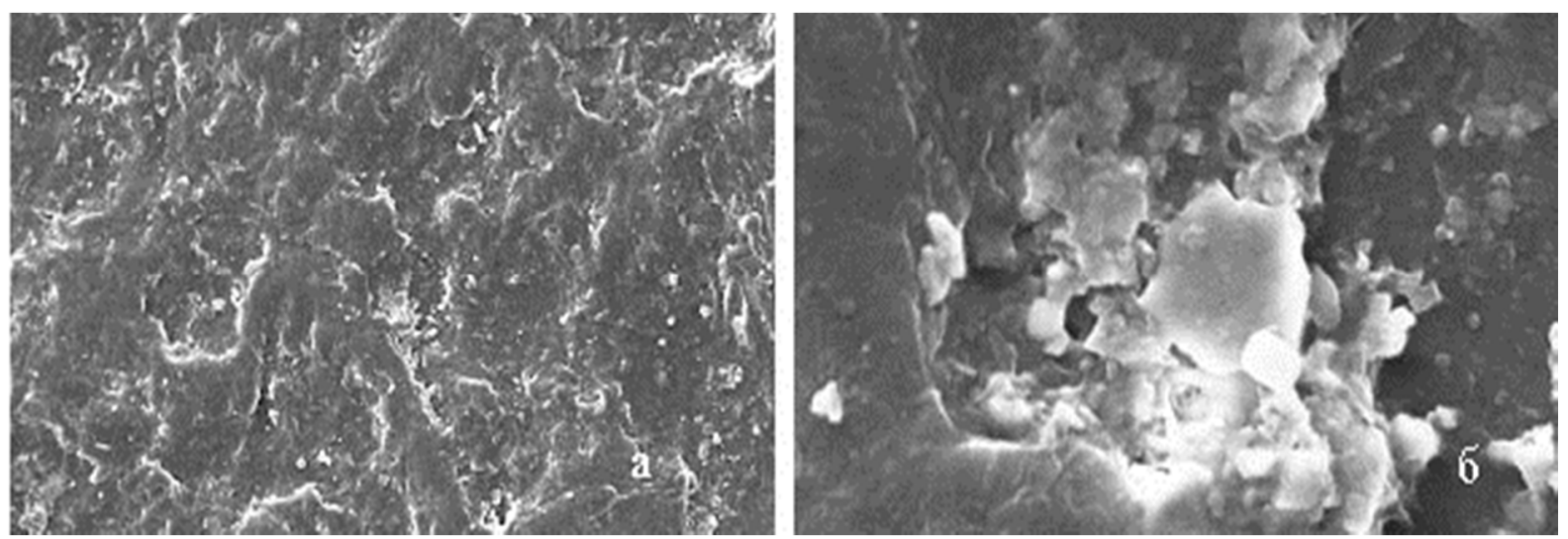

Fig. 3. The increasing of the defects on the pipe surface from the modified polyethylene material (PE2NT11-285D + 7 wt. \% thermo stabilizers) that functioned for 1 year: a - X 500; b - X 5000.

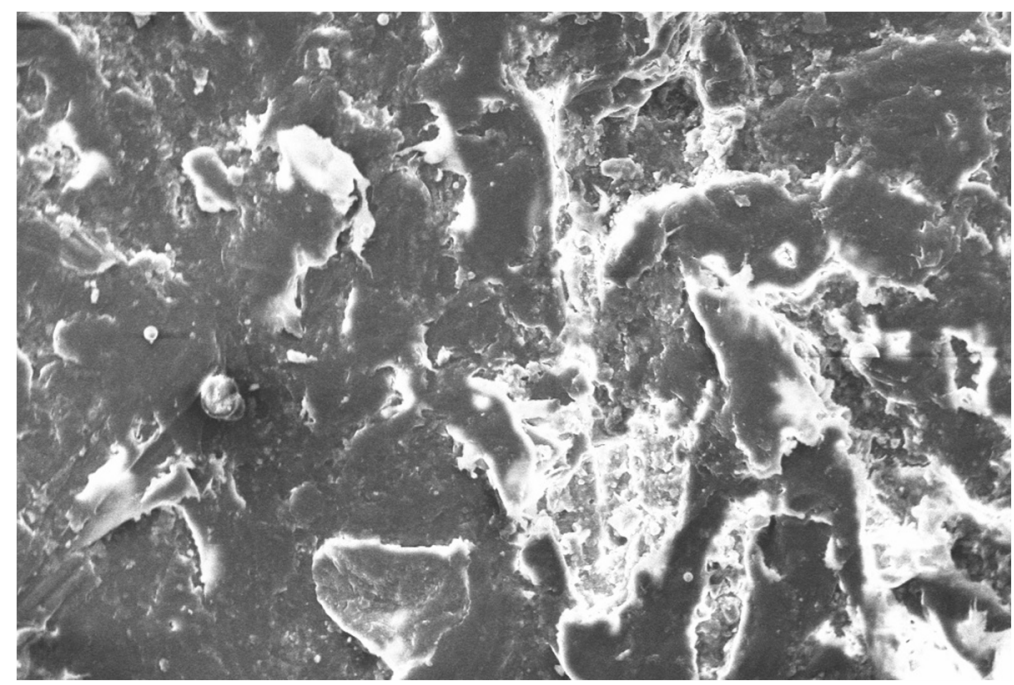

Fig. 4. Structure of polyethylene pipe surface (PE2NT11-285D + 7 wt. \% thermo stabilizers), which was in operation for 6 years (X 500).

durable and higher resistant to operating conditions compare to another tubes material. Material of such pipes has surface structure with fewer defects and highest mechanical properties (Fig. 5).

\section{III.Discussion}

The results of research of mechanical characteristics of polyethylene pipes for cold water were slightly different from his other researchers [2, 3]. The main differences in indexes of investigations were at level of research error. Modification of the materials, partial changes of their structure, leads to differences in physical and mechanical characteristics of the material that aggravated during storage, aging and operating of the products. Therefore, it is important to identify the areas of aging passing and predict product life cycle behavior in continuous operating under load at an early stage. The polyethylene is high flexible material that can resist sufficiently large deformations without losing their operability and can prevent such defects. However, the sudden shock load, shear deformation in certain conditions such as low temperatures can lead to brittle state of polyethylene $[4,5]$. In addition, the use of pipes for hot and cold water supply, sewage systems, gas supply found undesirable to the consumer trend in changes in the properties of any pipe material - the possibility of defects called "rapid cracks propagation" [6]. Therefore, one of the main characteristics that define the quality of a polyethylene composition for the production of pipes is a measure of "resistance to rapid crack propagation".

Research has established that modified composite polyethylene is the best suited as a material to water supply pipe, showing high characteristics of stability under constant internal pressure and shock loads falling cargo. This material less subject to structural changes, saves the initial phase composition, have a small degree of crystallization during aging and according to this surface structure have a small number of defects. A minor application of modifiers does not cause a deterioration of consumer and sanitation indexes of transported water [1]. Of course, the technology of manufacturing such pipes also requires some improvement, because of many initial defects can be 

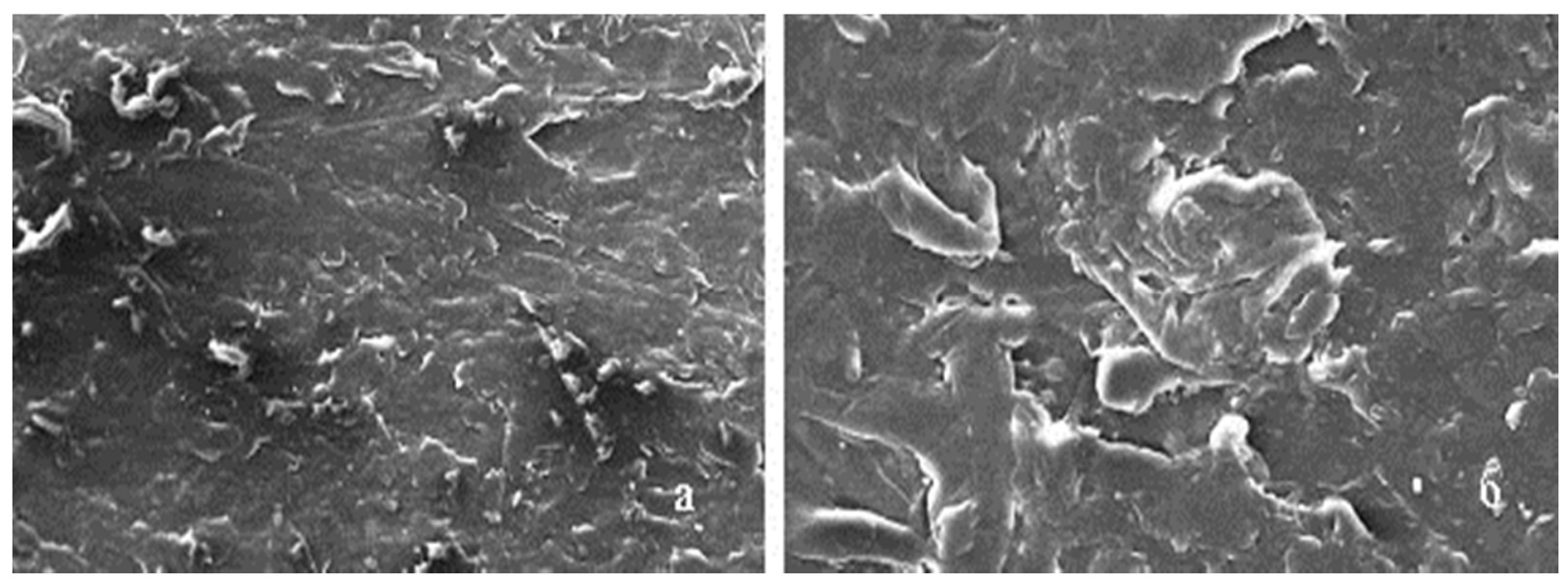

Fig. 5. The view of the pipe surface from modified polyethylene composite after 6 years of job (a - X 500; b - X 1000).

attributed to technological shortcomings production (inadequate temperature extruder head, lack of plasticizers) [7]. This places, in future during operating and aging, are areas of stress concentration which intensified due mechanical and thermo oxidative degradation, hydrolysis, that lead to a weakening of the mechanical characteristics of the material. However, investigation on materials pipes made of polyethylene of high and low pressure, which were in exploitation 15 years, found an interesting conformity to natural laws in the changing mechanical properties - improve the indexes of yield strength in tension during the first five years and decrease their values at further [8]. It is clear that such growth in mechanical properties is due to increase of crystallinity of polyethylene in the first years of exploitation. In the next operation, these indexes reduced due to the defects, which arise in matrix along division of amorphous and crystalline phase. These processes were not had disastrous consequences for pipe products, as used for irrigation works, where no further applied mechanical load, while mounting and during exploitation.

Surface texture of composite polyethylene materials, which include modifying applications and impurities, not subject to any changes even with the additional operating shock loads, and their mechanical properties are satisfactory for a long time. Thus, it found that the use of modified polyethylene composite for the manufacture of pipes for cold water line systems promotes long-term stabilization of the mechanical characteristics of the material.

Domantsevych N. - Professor, PhD;

Shunkina E. - Ph.D., assistant of professor; Yatsyshyn B. - Professor, PhD.

[1] N.I. Domantsevych, O.V. Shunkina, B.P. Yatsyshyn, Khmelnytsky National University Bulletin 221(1), 269 (2015).

[2] S.A. Kurt, V.S. Kurhanskyy, Chemistry and Technology of Macromolecular Compounds (Play Publishers, Ivano-Frankivsk, 2010).

[3] NEPROPLAST HDPE Pipes for Water, Gas \& Sewage Systems. Information resource: www.neproplast.com; www.namat.com.

[4] V. E. Gul', Structure and strength of polymers (Khimiya Publishers, Moscow, 1971).

[5] I. Narisawa, Strength of polymer materials (Khimiya Publishers, Moscow, 1987).

[6] M. Sezonov, Polymer pipes 5(4), 32 (2007).

[7] W. Baranowski, P. Palutkiewicz, K. Werner. Polymery 60(1), 66 (2015).

[8] A.M. Ollick, A.M. Al-Amri, Information resource: www.kfu.edu.sa/en/Deans/Research/Documents/1010.pdf. 


\title{
Н.І. Доманцевич, О.В. Шунькіна, Б.П. Яцишин
}

\section{Вплив умов експлуатації на структуру та фізичні властивості полімерних матеріалів}

\author{
Львівський торговельно-економічний університет, 79008, Україна, Львів, вул. Туган-Барановського, 10, \\ e-mail: nina.domantzevich@gmail.com; $\underline{\text { bogdan.yatsyshyn7@gmail.com }}$
}

Досліджено зміни структури та фізичних властивостей полімерних матеріалів, що експлуатувались тривалий час у напірних трубах водопровідних систем при періодичній дії механічних навантажень. Встановлено значне зниження механічних характеристик таких полімерних матеріалів. За допомогою електронно-мікроскопічних досліджень визначено найбільш характерні структурні дефекти, що виникають у полімерних матеріалах при виготовленні та експлуатації.

Ключові слова: полімерні матеріали, поліетилен, механічні характеристики, структура поверхні. 